\title{
Is climate change causing the increasing narwhal (Monodon monoceros) catches in Smith Sound, Greenland?
}

\author{
Martin Reinhardt Nielsen \\ Faculty of Life Sciences, University of Copenhagen, Bülowsvej 17, DK-1870 Frederiksberg C, Denmark
}

\author{
Keywords \\ Climate change; Greenland; Monodon \\ monoceros; Narwhal; whale management; \\ whaling.

\section{Correspondence} \\ Martin Reinhardt Nielsen, Faculty of Life \\ Sciences, University of Copenhagen, \\ Bülowsvej 17, DK-1870 Frederiksberg C, \\ Denmark.E-mail: nielsenmr@gmail.com
}

doi:10.1111/j.1751-8369.2009.00106.x

\begin{abstract}
This paper evaluates recent changes in narwhal (Monodon monoceros) catches in Siorapaluk, the northernmost community in Greenland, in consideration of the effects of changing climate and uncertainty of stock delineation. The catch statistics show a significant increase in narwhal catches by hunters in Siorapaluk after 2002, which does not appear to be a result of increased effort. Hunters attribute the increase to changed sea-ice conditions providing access by boat to Smith Sound as early as June and July. This indicates that climate change is likely to have a considerable impact on narwhal hunting in northern Greenland. Traditional ecological knowledge and scientific surveys suggest that narwhal in Smith Sound constitute an independent stock. The absence of scientific recommendations for this stock has been seen as an opportunity to increase quotas in West Greenland. Scientific management recommendations are urgently needed to allow the authorities to assign sustainable quotas for this stock. The development of collaborative management agreements and locally based monitoring are recommended to ensure local acceptance of regulations, and to allow rapid responses to climate change.
\end{abstract}

Three independent stocks of narwhal (Monodon monoceros) are currently recognized in Greenland waters (HeideJørgensen \& Laidre 2006). The summer stock at Inglefield Bredning, in Qaanaaq municipality, is considered to be the same stock that is caught in autumn and winter in Uummannaq municipality and the Disko Bay area (HeideJørgensen et al. 2005), with individuals straying only rarely as far south as Maniitsoq. This stock is referred to as the West Greenland stock. The summer stock in Melville Bay is caught by hunters from Upernavik municipality and from Savisivik in Qaanaaq municipality. This stock spends the winter in the central part of Baffin Bay (Dietz $\delta$ Heide-Jørgensen 1995). Narwhal in East Greenland are genetically distinct from stocks in West Greenland (Palsbøll et al. 1997), and are considered to comprise one stock, largely because of a lack of information (Nielsen, unpubl. ms.). Surveys reveal that the narwhal summer stock in Inglefield Bredning halved over the course of 20 years (Heide-Jørgensen et al. 2002). The West Greenland winter population has also been reduced, and the latest population assessment predicts local extinction of this stock in less than 30 years if current harvest levels continue (JCNB/ NAMMCO 2004). No reliable population estimates are available for the Melville Bay stock.
Quotas were introduced by the Greenland Home Rule Government through an executive order on protection and hunting of beluga and narwhal in 2004. Management advice is provided by the Canada-Greenland Joint Commission on Conservation and Management of Narwhal and Beluga (JCNB). The JCNB receives scientific recommendations on harvest sustainability by a Joint Working Group (JWG) comprising the JCNB Scientific Working Group and a working group from the Scientific Committee of the North Atlantic Marine Mammal Commission (NAMMCO). The JWG recommends a maximum catch of 135 narwhal from the West Greenland stock (Witting 2005). However, uncertainty surrounds the stock delineation of narwhal populations in Baffin Bay and the northern strait between Greenland and Canada, the so-called Smith Sound, which in the winter constitutes part of the North Water Polynya (Heide-Jørgensen et al. 2005). Unclear stock delineation and the lack of reliable population estimates prevent the assignment of population-specific quotas to the relevant Greenlandic municipalities, where isolated communities depend on narwhals as a source of nourishment and income (Stevenson et al. 1997; Freeman et al. 1998). The urgency to solve this problem increases as the Greenland 
Home Rule Government repeatedly exceeds quota allocations proposed by its Department of Fisheries, Hunting and Agriculture (DFFL). It is important to ensure that information on sustainable harvest levels is available for all stocks, so that the lack of information cannot be used as an argument for increasing quotas that would otherwise have been gradually reduced in accordance with scientific advice.

The potential effects of climate change on narwhal populations also remain uncertain. Generally, declining Arctic sea-ice trends are expected as a result of climate change (Symon et al. 2005; Solomon et al. 2007). Remotely sensed sea-ice concentrations in the period 1979-2001, however, indicate a decreasing fraction of open water and increasing interannual variability in narwhal wintering grounds in central Baffin Bay (Laidre \& Heide-Jørgensen 2005). These wintering grounds are critically important for narwhal energy intake and overall fitness, suggesting that recent changes entail an increased risk of ice entrapment and vulnerability (Laidre \& HeideJørgensen 2005). This result extends to Jones Sound in the North Water Polynya for the month of March (Heide-Jørgensen \& Laidre 2004). However, as sea-ice concentrations are primarily driven by wind and current patterns as well as by temperature (Heide-Jørgensen et al. 2007), trends may vary according to local conditions, and may result in less sea ice locally. The potential effects of reduced sea-ice cover on marine mammal stocks include nutritional stress resulting from the redistribution of prey, changes in survivorship or fecundity, and altered migration routes or timing caused by changing ice patterns (Simmonds \& Isaac 2007). The effects on higher tropic levels are, however, particularly difficult to investigate, because they involve relationships that may be nontrivial, non-linear and affected by time lags (Lusseau et al. 2004; Leaper et al. 2006). Furthermore, few studies have considered the impact of changing hunter behaviour as a result of climate change (but see Stirling \& Parkinson 2006). The aim of this paper is therefore to evaluate the recent changes in narwhal catches in Siorapaluk, in consideration of the effects of changing climate as well as the uncertainty of stock delineation.

\section{Study area}

Siorapaluk $\left(77^{\circ} 47^{\prime} \mathrm{N}, 70^{\circ} 43^{\prime} \mathrm{E}\right)$ is the northernmost community in Greenland and the one nearest to Smith Sound (Fig. 1). The community has a church, school, a general store and electricity, but no running water. There are approximately 60 inhabitants, of which 16 held an occupational hunter's license and seven held a part-time hunter's license in 2004. Almost all households depend on hunting and fishing for subsistence and income.
Halibut, seal, narwhal, walrus, polar bear, reindeer, muskoxen and various birds are caught. Sealskin and halibut are produced for the national market, but only in small quantities on account of limited local freezer capacity, and because the products have to be transported to Qaanaaq to be sold. Particularly valuable catches such as narwhal, which may bring in the equivalent of approximately 5800 USD for an adult (Nygård \& Topp-Jørgensen 2007), are also occasionally transported for marketing in Qaanaaq. However, often narwhal is not traded because it is considered to be of high cultural value, and important for the upkeep of social relationships through traditional sharing practices (Sejersen 2001). Hunting and fishing is carried out exclusively using dog sledges on the sea ice and from small dinghies. In accordance with Qaanaaq municipality by-laws, narwhal are hunted with handheld harpoons with attached floats, and from kayaks, which are transported to the hunting area by dinghies: sometimes dinghies are dragged over long stretches of sea ice. The actual kill is undertaken with a rifle once the narwhal has been secured with several floats.

\section{Methods}

Siorapaluk was selected as the focal research community as it had been identified as a location of a considerable increase in narwhal catches. The evaluation is based on quantitative and qualitative inquiry, including catch statistics, information on the number of hunters and focus group discussions. The Siorapaluk catch statistics were extracted from the national catch database, Piniarneq, for the period 1993-2004. All hunters record catches per month, and report their annual catch to the DFFL, which maintains the database. Reported catches were verified during meetings or subsequently by telephone. Prior to 2004, narwhal hunting was permitted for both occupational and part-time hunters. Information on the number of active hunters in the period 1993-2004 was extracted from the national hunting license register. Sufficiently detailed and reliable data are not available for Siorapaluk prior to the establishment of Piniarneq (see HeideJørgensen 1994). Statistical tests were conducted with SAS software. Correlations were tested with the Pearson product-moment correlation coefficient. Significant differences in the means were tested with the MannWhitney $U$-test.

Semi-structured focus group discussions (Bryman 2004; Lloyd-Evans 2006) on narwhal hunting, hunting methods and the impacts of climate change were conducted in Greenlandic, with the aid of a local interpreter, with 12 members from the local hunting organization, KNAPK, and four members of the village board, on 30 November and 1 December 2006, respectively. All 


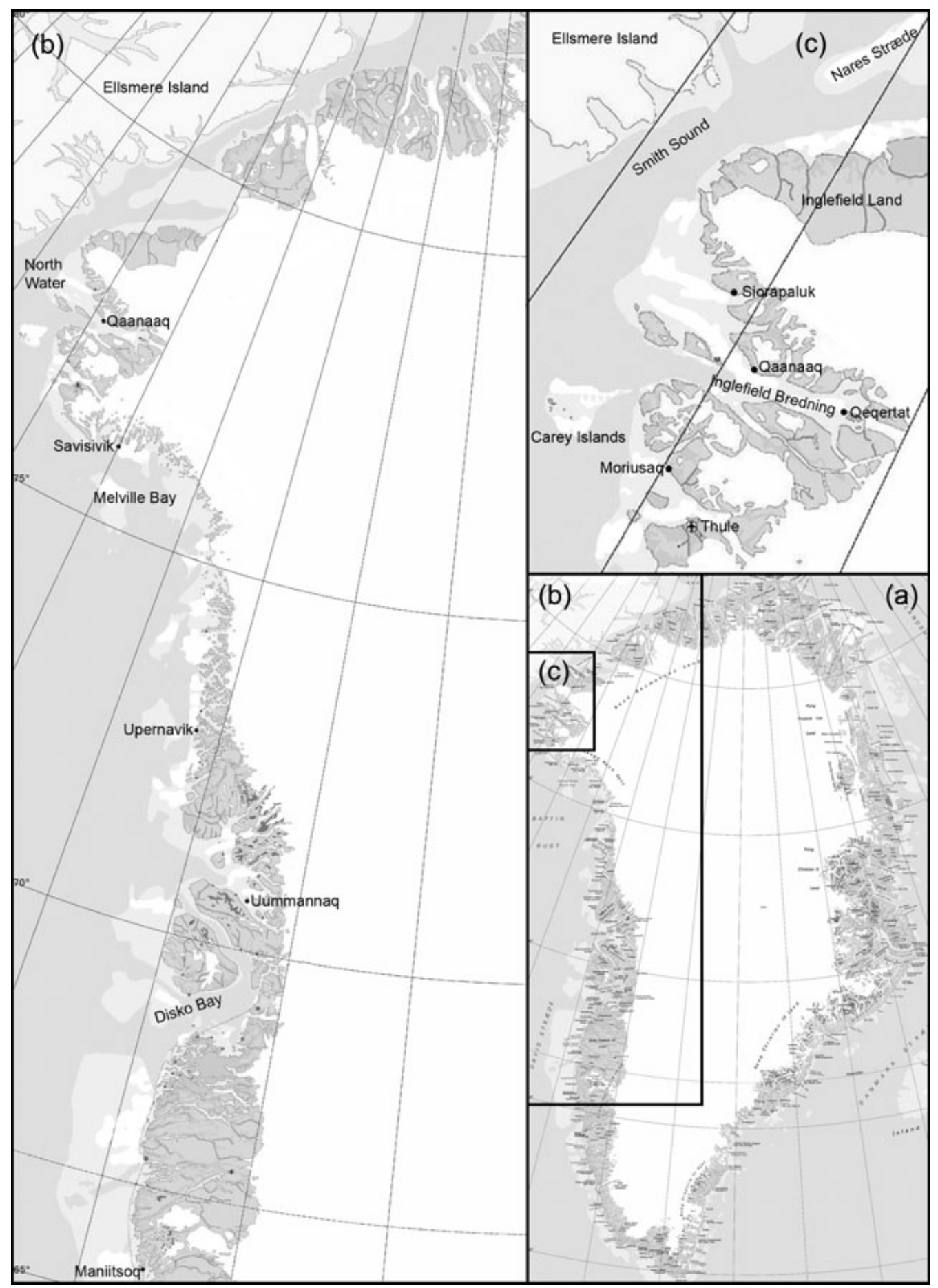

Fig. 1 Map of (a) Greenland, with insets (b) and (c) of the study area.

hunters in the community were invited for the discussion, and as more than half of the hunters and the village board participated in the discussion the results are considered to be representative for these groups. A meeting was also conducted with four members of the board of
KNAPK in Qaanaaq on 3 December 2006. This approach was selected so that information could be collected from the primary stakeholders, including individual hunters, local hunting organizations and local authorities. Semistructured focus group discussions were selected instead 
of more open-ended or structured methods, to ensure the collection of the required information while retaining a measure of flexibility (Bryman 2004; Lloyd-Evans 2006). The key points raised were reviewed with the local interpreter immediately after the focus group discussions, and after the completion of the fieldwork a summary report was forwarded to the local KNAPK and the village board for verification and validation, and to allow for the consideration and inclusion of further comments. The consensus results of the discussions are reported unless otherwise stated. Names of participants and respondents have been kept confidential to protect their privacy.

\section{Results}

The results (Fig. 2) illustrate a significant increase in narwhal catches by hunters in Siorapaluk after 1998, compared with previous data $\left(U_{6.6}=0 ; P<0.05\right)$. No significant correlation was found between the size of the catch and the total number of hunters $\left(r_{12}=0.42\right.$, $P>0.05)$, or the number of occupational hunters $\left(r_{12}=0.49, P>0.05\right)$, suggesting that the increased catch is not a result of increased effort, assuming that hunting technology and the narwhal distribution have remained relatively stable throughout the period. These assumptions may not be valid, and will be considered in the discussion.

Hunters in Siorapaluk attribute the increased catch to the changing sea-ice conditions in Smith Sound. Previously, narwhal populations in Smith Sound were only accessible by dog sledge on the sea ice, and, according to the hunters, no one travelled there to hunt narwhal. One hunter from Siorapaluk recalled traveling to Smith Sound by dog sledge in May 1976 on a polar bear hunt, and seeing large pods of narwhal. According to the hunters, the formation of the ice is occurring later, the ice is thinner, it breaks up earlier, and, since 1998, Smith Sound can therefore be accessed by boat as early as June

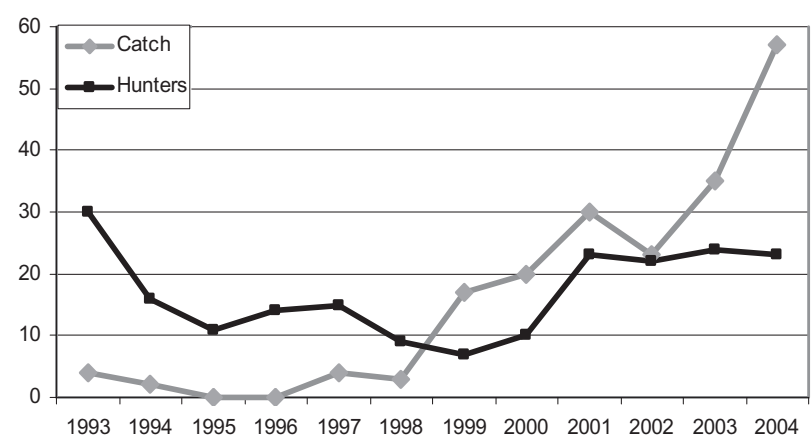

Fig. 2 Narwhal catch by hunters from Siorapaluk and total number of hunters in the period 1993-2004. or July. This is supported by a substantial change in the distribution of the catch, with the bulk of the catch caught in June and July after 1998 (Fig. 3).

A more detailed look at the catch statistics, breaking it down into three periods, indicates a close connection between the catch and the number of hunters in the period 1993-98 (see Fig. 2), although no significant correlation was found $\left(r_{6}=0.48, P>0.05\right)$. The increasing number of hunters from 1999 to 2001 may explain the increasing catch in this period. However, from 2002 the number of hunters has remained stable, whereas the catch has almost tripled. This suggests that that effect of changing ice conditions on narwhal hunting, as emphasized by the hunters, cannot be disentangled from the effects of increased effort, until 2002. From July 2004 quotas were introduced on narwhal hunting in West Greenland. Unfortunately, remotely sensed sea-ice data are not readily available at sufficient spatial and temporal resolution for Smith Sound to enable correlation tests with the catch from 1993 to 2004 (Laidre, pers. comm.). Similarly, the air-temperature records available from Qaannaq and the Carey Islands are of dubious utility in this context, because of the distance from Smith Sound, and because local sea-ice concentrations are determined by wind and current patterns, as well as by temperature (Heide-Jørgensen et al. 2007). Assessing the correlations reported here with measures of climate change is thus beyond the scope of this study. Documentation of similar changes in sea-ice cover is, however, abundant from other locations in the Arctic, and will be considered in the discussion.

Hunters in Siorapaluk consider the narwhal in Smith Sound to be a separate population that either migrates between Canada (Ellesmere Island and Humbolt Brink) and Greenland, or remains in Smith Sound all year round. According to local knowledge, the winter population is very variable. Narwhal hunting in Smith Sound is primarily carried out by hunters from Siorapaluk, but hunters from Qaanaaq and perhaps Moriusaq are

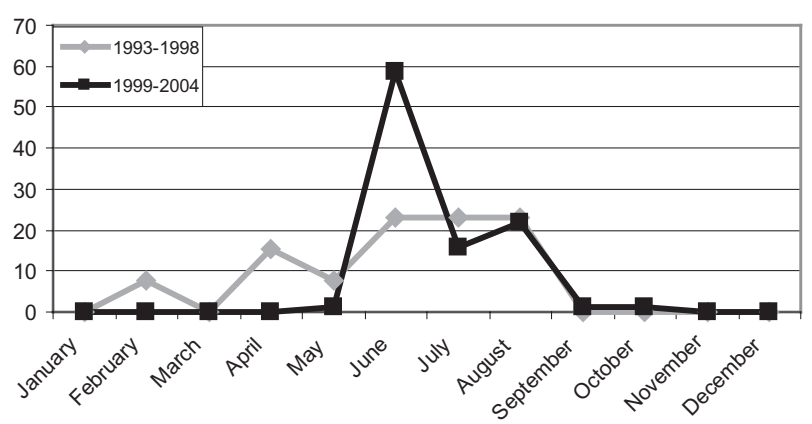

Fig. 3 Percentage of accumulated narwhal catches by hunters in Siorapaluk per month, before and after 1998. 
increasingly targeting this area as well. This means that the increase in the catch in Smith Sound may be higher than Fig. 2 indicates. According to the KNAPK in Qaanaaq, approximately three boats from Qaanaaq hunt narwhal in Smith Sound, and annually return with between one and three narwhal each. It was also rumoured that unlicensed hunting is on the increase. The window of opportunity is, however, decreasing: according to the hunters, the break-up of the ice occurs earlier and earlier, causing the narwhal to disperse and head to the fjords.

\section{Discussion and recommendations}

The hunters' observations of changes in sea ice correspond to scientifically documented changes in sea-ice cover, ice thickness, and dates of freeze and break-up in the Arctic (Johannessen et al. 1999; Maslanik et al. 1999; Parkinson et al. 1999; Rothrock et al. 1999; Copley 2000; Rigor et al. 2002; Rothrock et al. 2003; Serreze et al. 2003; Comiso \& Parkinson 2004; Fowler et al. 2004; Gough, Cornwell et al. 2004, Gough, Gagon et al. 2004; Gagon \& Gough 2005; Lindsay \& Zhang 2005; Rothrock \& Zhang 2005; Stroeve et al. 2005; Stirling \& Parkinson 2006). They also correspond to changes observed by Inuit in other parts of the Arctic (see review in Laidler 2006). These changes are considered to be the result of anthropogenic climate change (Solomon et al. 2007). The results indicate that climate change is likely to have been making a considerable impact on narwhal hunting in Smith Sound since 2002, and potentially since 1999.

This conclusion is based on the assumption that hunting technology and narwhal distribution and stock size have remained stable. All vessels used by occupational hunters must be registered in the Greenland vessel register managed by the Greenland Fisheries License Office (GFLK). GFLK has, however, only received three reports from Qaanaaq municipality. The reports mention one vessel in 1992, two more in 1993 and another two in 1999, bringing the total to five dinghies in Siorapaluk, all below 4 gross metric tonnes. The Danish Maritime Authority registered one vessel in Siorapaluk in a survey in 2000, and none in 2007. However, in the period 2000-02, about 13600 USD was allotted to support the purchase of three 19-foot/115-horsepower dinghies by occupational hunters in Siorapaluk, from the Home Rule Government's fund for development of the hunting sector. No information is available on vessels owned by part-time hunters. Because of the incomplete information about vessels in use, it cannot be ruled out that improvement in technology has had an effect on narwhal hunting by hunters from Siorapaluk. Based on the available information and observations of vessels, and the lack of snowmobiles in Siorapaluk, it is, however, considered unlikely that improved technology is the main reason for the increase in catch from an average of two whales per year from 1993 to 1998 (95\%; CI [confidence interval] \pm 0.05 ), to 30 whales per year from 1999 to 2004 (95\%; CI \pm 0.37).

Aerial surveys conducted in June recorded narwhals in Smith Sound at the same time as pods were observed at Inglefield Bredning (Koski \& David 1994). This indicates that the Smith Sound pods belong to an independent population, which also accords with local knowledge. In combination with the reduction of narwhal stocks at Inglefield Bredning (Heide-Jørgensen et al. 2002), primarily attributed to unsustainable exploitation, this indicates that the increased catch is not caused by a change in the narwhal distribution. However, it cannot be excluded that a potential increase in stock size has contributed to the increased catch by hunters in Siorapaluk, although this is unlikely given the general declining trend in narwhal stocks in Greenland for the period (Born et al. 1994; Heide-Jørgensen et al. 2002; Heide-Jørgensen \& Acquarone 2002; Heide-Jørgensen 2004; JCNB/ NAMMCO 2004).

As no abundance estimates exist for Smith Sound, no information is available on sustainable catch levels for this stock. The optimal sustainable use of all Greenlandic narwhal populations is imperative, in consideration of the cultural and economic importance of narwhal hunting (Sejersen 2001). With the introduction of quotas from July 2004, catches have been reduced drastically, and hunters struggle to find alternative incomegenerating activities. Hunting is a central part of Greenlandic culture and identity, and the Greenlandic hunter's organization, KNAPK, has strong political support. The existence of a population of narwhal in Smith Sound for which scientific recommendations are lacking has been seen as an opportunity to increase narwhal quotas in West Greenland. Coupled with the effects of climate change, which appear to be accelerating and leading to changes in sea-ice cover earlier than expected (Holland et al. 2006; Stroeve et al. 2007; Serreze et al. 2007), this could have serious detrimental implications for narwhal stocks.

The DFFL have been attempting to reduce quotas gradually to the scientifically recommended sustainable levels in order to give narwhal hunter's time to adapt and develop alternative income options. However, in the quota year 2005-06, the Home Rule Government added 50 extra narwhal to the quota of 260 whales recommended by the DFFL for West Greenland, a number that already greatly exceeded the recommended harvest of 135 whales from the West Greenland stock (no recommendation is available for the Melville Bay stock). In 
December 2006 an additional 100 animals were allotted to the 2006-07 quota of 285 whales. In July 2007, an initial quota of 300 whales was allocated for the quota year 2007-08. The Home Rule Government simultaneously pledged in a press release to develop a plan to reduce quotas to levels in accordance with scientific advice by April 2008. However, the quota for the year 2008-09 was again set at 300 animals, and by December 2008 a plan had not yet been produced. Instead, 90 animals had been allocated in addition to the initial quota. In a press release by the Home Rule Government this was justified on the basis of the fact that the hunters had applied for additional whales. On a more positive note, a preliminary analysis of new data indicates a higher abundance of narwhal than has previously been assumed (NAMMCO 2008).

Scientific recommendations are urgently needed to allow authorities to assign sustainable quotas for the Smith Sound population of narwhals. To prevent untimely interference by politicians in quota allocation, and to ensure compliance and optimal adaptation to local circumstances, collaborative management agreements should be developed with local hunter organizations. This could ensure local acceptance of regulations, and thus prevent the inclination for politicians to allot extra quotas to show their support for the hunters and gain local popularity and votes.

Collaborative management could also include a jointly developed monitoring strategy (Huntington 2000; Russel et al. 2000; Harwood et al. 2002). This should, in addition to scientific population counts, use the large and costefficient data potential of systematically recorded quantitative observations from the hunters (Kofinas et al. 2001; Moller et al. 2004; see also Danielsen et al. 2000), who regularly traverse Smith Sound and other narwhal areas. This would give hunters a valid basis for their arguments in discussions on quota allocations, and could provide biologists with an indirect measure of population trends and other information in the periods between scientific counts (Fernandez-Gimenez et al. 2006), and would therefore permit rapid management responses to changing circumstances, occurring as a result of climate change for instance.

Although not unproblematic (Richard \& Pike 1993; Collings 1997; Kruse et al. 1998; Klein et al. 1999; Kaplan \& McCay 2004; Tyrrell 2007; Fernandez-Gimenez et al. 2008), co-management initiatives could ease a strained relationship between biologists and hunters, who have been in strong opposition since the introduction of quotas in Greenland (Sejersen 2003). Recently, a collaboration agreement was signed between KNAPK and the Greenland Institute of Natural Resources. Hopefully this can help ensure that the common goals of large viable popu- lations, and compliance with international agreements that Greenland has adopted, are achieved.

\section{Acknowledgements}

I want to thank the people of Siorapaluk for their hospitality, and the hunter's organizations and local administration in Siorapaluk and Qaanaaq for providing information for this study. Thanks also to the Hunting Division of the Directorate for Fisheries, Hunting and Agriculture for access to catch statistics and other information, and to Kristine Laidre, Mads Peter Heide-Jørgensen, Elmer Topp-Jørgensen, Erik W. Born, Fernando Ugarte and Natasja Kingod for useful information and comments on earlier drafts of the manuscript.

\section{References}

Born E.W., Heide-Jørgensen M.P., Larsen. F. \& Martin A.R. 1994. Abundance and stock composition in Inglefield Bredning (NW Greenland). Meddelelser om Gronland. Bioscience 39, 51-68.

Bryman A. 2004. Social research methods. Second edn. Oxford: Oxford University Press.

Collings P. 1997. Subsistence hunting and wildlife management in the central Canadian Arctic. Arctic Anthropology 34, 41-56.

Comiso J.C. \& Parkinson C.L. 2004. Satellite-observed changes in the Arctic. Physics Today 57(8), 38-44.

Copley J. 2000. The great ice mystery. Nature 408, 634-636.

Danielsen F., Balete D.S., Poulsen M.K., Enghoff M., Nozawa C.M. \& Jensen A.E. 2000. A simple system for monitoring biodiversity in protected areas of a developing country. Biodiversity and Conservation 9, 1671-1705.

Dietz R. \& Heide-Jørgensen M.P. 1995. Movements and swimming speed of narwhals (Monodon monoceros) instrumented with satellite transmitters in Melville Bay, northwest Greenland. Canadian Journal of Zoology 73, 2106-2119.

Fernandez-Gimenez M.E., Huntington H.P. \& Frost K.J. 2006. Interaction or co-optation? Traditional knowledge and science in the Alaska Beluga Whale Committee. Environmental Conservation 33, 306-315.

Fernandez-Gimenez M.E., Hays J.U., Huntington H.P., Andrew R. \& Goodwin W. 2008. Ambivalence towards formalizing customary resource management norms among Alaska Native beluga whale hunters and Tohono O'odham livestock owners. Human Organization 67, 137-150.

Freeman M.M.R., Bogoslovskaya L., Caulfield R.A., Egede I., Krupnik I.I. \& Stevenson M.G. 1998. Inuit, whaling and sustainability. Walnut Creek, CA: Altamira Press.

Fowler C., Emery W.J. \& Maslanik J. 2004. Satellite-derived evolution of Arctic sea ice age: October 1978 to March 2003. IEEE Geosciences Remote Sensing Letters 1, 71-74. 
Gagnon A.S. \& Gough W.A. 2005. Climate change scenarios for the Hudson Bay region: an intermodel comparison. Climatic Change 69, 269-297.

Gough W.A., Cornwell A.R. \& Tsuji L.J.S. 2004. Trends in seasonal sea ice duration in southwestern Hudson Bay.Arctic 57, 299-305.

Gough W.A., Gagon A.S. \& Lau H.P. 2004. Interannual variability of Hudson Bay ice thickness. Polar Geography 28, 222-238.

Harwood L.A., Norton P., Day B. \& Hall P.A. 2002. The harvest of beluga whales in Canada's western Arctic: hunter-based monitoring of size and composition of the catch. Arctic 55, 10-20.

Heide-Jørgensen M.P. 1994. Distribution, exploitation and population status of white whales (Delphinapterus leucas) and narwhals (Monodon monoceros) in West Greenland. Meddelelser fra Grønland. Bioscience 39, 135-149.

Heide-Jørgensen M.P. 2004. Aerial digital photographic surveys of narwhal, Monodon monoceros, in West Greenland. Marine Mammal Science 20, 246-261.

Heide-Jørgensen M.P. \& Acquarone M. 2002. Size and trends of the bowhead whale, beluga and narwhal stocks wintering off West Greenland. NAMMCO Scientific Publications 4, 191-210.

Heide-Jørgensen M.P., Dietz R. \& Laidre K. 2005. Metapopulation structure and hunt allocation of narwhals in Baffin Bay. In: NAMMCO Annual Report. Pp. 221-223. Tromsø: North Atlantic Marine Mammal Commission.

Heide-Jørgensen M.-P., Hemmeken N. \& Hollebeek P. 2002. Optælling af Narhvaler i Qaanaaq Kommune i august 2001. (Census of narwhal in Qaanaaq municipality in August 2001.) Teknisk Rapport 50. Nuuk: Institute of Natural Resources.

Heide-Jørgensen M.P. \& Laidre K.L. 2004. Declining extent of open water refugia for top predators in Baffin Bay and adjacent waters. Ambio 33, 488-495.

Heide-Jørgensen M.P. \& Laidre K. 2006. Greenland's winter whales: beluga, narwhal and bowhead whale. Nuuk: Ilinniusiorfik Undervisningsmiddelforlag.

Heide-Jørgensen M.P., Stern H. \& Laidre K.L. 2007. Dynamics of the sea ice edge in Davis Strait. Journal of Marine Systems 67, 170-178.

Holland M.M., Blitz C.M. \& Tremblay B. 2006. Future abrupt reductions in the summer Arctic sea ice. Geophysical Research Letters 33, article no. L23503.

Huntington H.P. 2000. Using traditional ecological knowledge in science: methods and applications. Ecological Applications 10, 1270-1274.

JCNB (Canada-Greenland Joint Commission on Conservation and Management of Narwhal and Beluga)/ NAMMCO (North Atlantic Marine Mammal Commission) 2004. Joint Meeting of the NAMMCO Scientific Committee Working Group on the Population Status of Narwhal and Beluga in the North Atlantic and the Canada/Greenland Joint Commission on Conservation and Management of Narwhal and Beluga Scientific Working Group. 3-6 February 2004. Tromsø, Norway: North Atlantic Marine Mammal Commission.
Johannessen O.M., Shalina E.V. \& Miles M.W. 1999. Satellite evidence for an Arctic sea ice cover in transformation. Science 286, 1937-1939.

Kaplan I.M. \& McCay B.J. 2004. Cooperative research, co-management and the social dimension of fisheries science and management. Marine Policy 28, 257-258.

Klein D.R., Moorehead L., Kruse J. \& Braund S.R. 1999. Contrasts in use and perceptions of biological data for caribou management. Wildlife Society Bulletin 27, 488-498.

Kofinas G., Lyver P., Russell D., White R., Nielson A. \& Flanders N. 2001. Towards a protocol for community monitoring of caribou body condition. Rangifer 14, 43-52.

Koski W.R. \& David R.A. 1994. Distribution and numbers of narwhals (Monodon monoceros) in Baffin Bay and Davis Strait. Meddelelser om Grønland. Bioscience 39, 15-40.

Kruse J., Klein D., Braund S., Moorehead L. \& Simeon B. 1998. Co-management of natural resources: a comparison of two caribou management systems. Human Organization $57,447-458$.

Laidler G.J. 2006. Inuit and scientific perspectives on the relationship between sea ice and climate change: the ideal complement? Climate Change 78, 407-444.

Laidre K.L. \& Heide-Jørgensen. M.P. 2005. Arctic sea ice trends and narwhal vulnerability. Biological Conservation 121, 509-517.

Leaper R., Cooke J., Trathan P., Reid K., Rowntree V. \& Payne R. 2006. Global climate drives southern right whale (Eubalaena australis) population dynamics. Biology Letters 2, 289-292.

Lindsay R.W. \& Zhang J. 2005. The thinning of Arctic sea ice, 1988-2003: have we passed a tipping point? Journal of Climate 18, 4879-4894.

Lloyd-Evans S. 2006. Focus groups. In V. Desai \& D. Potter (eds.): Doing development research. Pp. 153-163. London: Sage Publications.

Lusseau D., Williams R., Wilson B., Grellier K., Barton T.R., Hammond P.S. \& Thompson P.M. 2004. Parallel influences of climate on the behavior of Pacific killer whales and Atlantic bottlenose dolphins. Ecology Letters 7, 10681076.

Maslanik J.M., Serreze M.C. \& Agnew T. 1999. On the record reduction in the western Arctic sea ice cover in 1998. Geophysical Research Letters 26, 1905-1908.

Moller H., Berkes F., Lyver P.O. \& Kislaioglu M. 2004. Combining science and traditional ecological knowledge: monitoring populations for co-management. Ecology and Society 9(3), article no. 2.

NAMMCO (North Atlantic Marine Mammal Commission) 2008. Scientific Committee. Report of the fifteenth meeting. Qeqertarsuaq, Greenland. 11-14 April 2008. Tromsø, Norway: North Atlantic Marine Mammal Commission.

Nygård L.A. \& Topp-Jørgensen J.E. 2007. Paper on significant trade review: beluga whale, narwhal, Atlantic walrus and polar bear. Nuuk: Hunting Department, Ministry of Fisheries, Hunting and Agriculture.

Palsbøll P.J., Heide-Jørgensen M.P. \& Dietz R. 1997. Population structure and seasonal movements of narwhals, 
Monodon monoceros, determined from mtDNA analysis. Heredity 78, 284-292.

Parkinson C.L., Cavalieri D.J., Gloersen P., Zwally H.J. \& Comiso C.J. 1999. Arctic sea ice extents, areas and trends, 1978-1996. Journal of Geophysical Research-Oceans 104, $20837-20856$.

Richard P.R. \& Pike D.G. 1993. Small whale co-management in the eastern Canadian Arctic: a case history and analysis. Arctic 46, 138-143.

Rigor I.G., Wallace J.M. \& Colony R.L. 2002. Response of sea ice to the Arctic oscillation. Journal of Climate 15, 2648-2663.

Rothrock D.A., Yu Y. \& Maykut G.A. 1999. Thinning of the Arctic sea ice cover. Geophysical Research Letters 26, 3469-3472.

Rothrock D.A., Zhang J. \& Yu Y. 2003. The Arctic sea ice anomaly of the 1990s: a consistent view from observations and models. Journal of Geophysical Research-Oceans 108, article no. 3083.

Rothrock D.A. \& Zhang J. 2005. Arctic Ocean sea ice volume: what explains its recent depletion? Journal of Geophysical Research-Oceans 110, article no. C01002.

Russel D., Kofinas G. \& Griffith B. 2000. Need and opportunity for a North American caribou knowledge cooperative. Polar Research 19, 117-130.

Sejersen F. 2001. Hunting and management of beluga whales (Delphinapterus leucas) in Greenland: changing strategies to cope with new national and local interests. Arctic 54, 431-443.

Sejersen F. 2003. Grønlands naturforvaltning: ressourcer og fangstrettigheder. (Greenland's nature management: resources and hunting rights.) Copenhagen: Akademisk Forlag.

Serreze M.C., Holland M.M. \& Stroeve J. 2007. Perspectives on the Arctic's shrinking sea-ice cover. Science 315, 1533-1536.

Serreze M.C., Maslanik J.A., Scambos T.A., Fetterer F., Stroeve J., Knowles K., Fowler C., Drobot S., Barry R.G. \& Haran T.M. 2003. A record minimum Arctic sea ice extent and area in 2002. Geophysical Research Letters 30, article no. 1110 .
Simmonds M.P. \& Isaac S.J. 2007. The impacts of climate change on marine mammals: early signs of significant problems. Oryx 41, 19-26.

Solomon S., Qin D., Manning M., Chen Z., Marquis M., Averyt K., Tignor M.M.B. \& Miller H. L. Jr. (eds.) 2007. Climate change 2007. The physical science basis. Contribution of Working Group I to the fourth assessment report of the Intergovernmental Panel on Climate Change. Cambridge: Cambridge University Press.

Stevenson M.G., Madsen A. \& Maloney E. 1997. The anthropology of community-based whaling in Greenland. Edmonton: Canadian Circumpolar Institute, University of Alberta.

Stirling I. \& Parkinson C.L. 2006. Possible effects of climate warming on selected populations of polar bears (Ursus maritimus) in the Canadian Arctic. Arctic 59, 261-275.

Stroeve J.C., Serreze M.C., Fetterer F., Arbetter T., Meier W., Maslanik J. \& Knowles K. 2005. Tracking the Arctic's shrinking ice cover: another extreme September minimum in 2004. Geophysical Research Letters 32, L04501, doi: 10.1029/2004GL021810.

Stroeve J., Holland M.M., Meier,W., Scambos T. \& Serreze M. 2007. Arctic sea ice decline: faster than forecast? Geophysical Research Letters 34, article no. L09501.

Tyrrell M. 2007. Sentient beings and wildlife resources: Inuit, beluga whales and management regimes in the Canadian Arctic. Human Ecology 35, 575-586.

Symon C., Arris L. \& Heal B. 2005. Arctic climate impact assessment. Cambridge: Cambridge University Press.

Witting L. 2005. A model selection based assessment for West Greenland narwhals with uncertain stock structure. In: Final report. Joint Meeting of the NAMMCO Scientific Committee Working Group on the Population Status of Narwhal and Beluga in the North Atlantic and the Canada/Greenland Joint Commission on Conservation and Management of Narwhal and Beluga Scientific Working Group. 13-16 October 2005.

Nuuk, Greenland, October 2005. Pp. 15-16. Tromsø, Norway: North Atlantic Marine Mammal Commission. 